\title{
A redescription of Trichillum hirsutum Boucomont with notes on other interesting brazilian Scarabaeinae (Coleoptera: Scarabaeidae).
}

\author{
Brett C. Ratcliffe (*)
}

\section{Abstract}

Trichillum hirsutum Boucomont (Coleoptera: Scarabeidae: Scarabaeinae) is redescribed because of errors in the original description. New distribution records are presented for Trichillum hirsutum Boucomont, Ipselissus alvarengai Pereira and Martinez (new state records); and Trichillum boucomonti Saylor and Cryptccanthon peckorum Howden (new country records for Brazil).

I recently took the opportunity to examine Boucomont's type specimen of Trichillum hirsutum which is deposited at the Muséum National d'Histoire Naturelle in Paris. This examination was necessary so that I could determine the differences between $T$. hirsutum and a new Trichillum described from the Amazon Basin of Brazil (Ratcliffe, in press). In adidition, $T$. hirsutum has ostensibly been considered a nomen dubium and was assigned the status of incertae sedis by Martinez (1967) in his review of the genus Trichillum, and I felt it was necessary to resolve this dilemma so that reliable taxonomic and ecological studies dealing with Trichillum could progress.

Heretofore, T. hirsutum was apparently known only from the original description (1928) which was brief and, in fact, erroneous. This situation has led to confusion and doubt among Trichillum workers as to where to place $T$. hirsutum and what characters to assign this taxon. See, for example, Martinez (loc. cit.) (who questioned the generic placement of $T$. hirsutum), Saylor (1935) (whose T. boucomon$t i$ is largely inseparable from $T$. hirsutum based on the descriptions), and Arrow (1932) and Balthasar (1939) (who discussed or keyed $T$. hirsutum based on the erroneous information given in the original description) .

The following is a redescription of the holotype female of $T$. hirsutum Boucomont:

\section{Trichillum hirsutum Boucomont}

Type Material. - Holotype female, labeled (1) "Bresil, São Paulo", (2) "ex Museo N. Van de Poll", (3) "TYPUS" (in red), (4) "Trichillum hirsutum n. sp." (hand written), (5) "Museum Paris, Boucomont."

Holotype. - Female. Length $4.0 \mathrm{~mm}$; greatest width $2.4 \mathrm{~mm}$. Color piceous, shining between punctures.

Head: Frons and clypeus moderately. setigerously punctate; punctures large, deep, separated by 1-3 diameters; setae long, erect, straw colored. Surface between punctures impunctate, minutely coriarious. Frontoclypeal carina weakly indicated, broadly interrupted at middle. Apex of clypeus with 2 rounded, acute teeth, notch between teeth broadly triangular; laterad of each tooth a distinct clypeal swelling on margin, distinct from ocular sweiling. Eyes difficult to see due to coating of greasy debris (even after extended sonic cleaning) but apparently very narrow.

Metasternum: weakly convex between middle coxae; sparsely, setigerously punctate; punctures large, deep, separated by 1-3 diameters. Setae long, straw colored.

Pronotum: Widest at base, sides gently curved, basal angle obtuse, anterior angle barely obtuse. Surface densely, setigerously punctate; punctures on disc moderate to large, deep, separated by 1-3 diameters; punctures on sides and margins becoming larger, denser, separated by less than 1 diameter; setae long, erect, straw colored. Surface between punctures minutely coriarious. Base narrowly margined

Elytra: Sutural stria absent. Each stria a deeply impressed, continuous line; punctures within the stria only weakly indicated. Intervals

(*) - Systematics Research Collections, W436 Nebraska Hall, University of Nebraska, Lincoln, Nebraska, 68588, U.S.A. 
between striae weakly convex, nearly smooth except for a single strong row of setigerous punctures running length of each stria; intervals 1-2 with row on lateral margin of interval, remaining intervals with row on median margin of interval; punctures large, deep, separated by 1-4 diameters; setae long, erect, straw colored.

Pygidium: Weakly convex in lateral view. Surface sparsely, setigerously punctate; punctures moderate in size, shallow, separated by 1-3 diameters; setae moderate in length, erect, straw colored. Posterior border margined.

Legs: Foretibia with 3 very strong teeth on lateral edge in apical $2 / 3$; teeth long, triangular, acute; apical tooth twice as long as basal tooth.

Remarks. - The prinicpal discrepancy betweer: the description of $T$. hirsutum and the type specimen of $T$. hirsutum revolves around the punctation of the elytral intervals. Boucomont described them (in Latin and French) as being biseriately punctate when, in fact, they are uniseriately punctate in the type. In the first two intervals of the type, the row of setigerous punctures is median, and in the remaining intervals the row of setigerous punctures is lateral. However, there is stıll only a single row per interval and not two. The original description was not accurate in describing a very important character, and problems were encountered or errors made based upon subsequent use by later authors of the faulty description.

I have also concluded that $T$. hirsutum is indeed a Trichillum and not a Pedaridium (as queried by Martinez, loc. cit.), and that it belongs in the subgenus Eutrichillum which now contains seven species. A key to these species is found in Ratcliffe (in press).

During my stay in Manaus, Amazonas, Brazi!, I collected a number of Trichillum hirsutum from baited pitfall traps. These specimens conform well to the type of $T$. hirsutum. In one 56 week study (in primary forest at Reserva Ducke, $26 \mathrm{~km}$ NE Manaus), one specimen was taken in a trap baited with faces, and 11 were taken in traps baited with carrion. In a separate 43 week study (in secondary forest on the campus of INPA-Manaus), one specimen was taken in a trap baited with feces, and 15 were taken in traps baited with carrion. These data suggest that $T$. hirsutum prefers carrion over feces as a food source. The same can be said for $T$. boucomonti Saylor (see below) and for an undetermined Trichillum from Leticia, Amazonas, Colombia (Howden \& Nealis, 1975).

Trichillum hirsutum was described from São Paulo. My collection from Amazonas constitute a new STATE RECORD for this species in Brazil and represent a considerable range extension of approximately $2700 \mathrm{~km}$.

\section{ADDITIONAL RECORDS}

The following information, also based on my collecting in Manaus, constitute new distributional records (Fig. 1) and are here listed:

Trichillum boucomonti Saylor. BRAZIL: Amazonas, Reserva Ducke, 26 km NE Manaus, all months 1977-1978. Collected from baited pitfall traps in primary forest over a 56 week period as follows: feces -18 specimens; carrion -76 specimens. The food prerefence for this species, as with T. hirsutum, is for carrion. New Country Record. Previously known only from Paraguay (Saylor, 1935) .

Cryptocanthon peckorum Howden. Brazil: Amazonas, Reserva Ducke, $26 \mathrm{~km}$ NE Manaus, all months 1977-1978. Collected from baited pitfall traps in primary forest over a 56 week period as follows: feces -110 specimens; carrion -14 specimens. The trapping results indicated here demonstrate a preference for feces as a food source. New Country Record. Previously known oniy from Colombia (Howden, 1973).

Ipselissus alvarengai Pereira and Martinez. Brazil: Amazonas, Reserva Ducke, $26 \mathrm{~km}$ NE Manaus, August only, and Manaus, all months except June and October - December. Ipselissus alvarengai was col- 


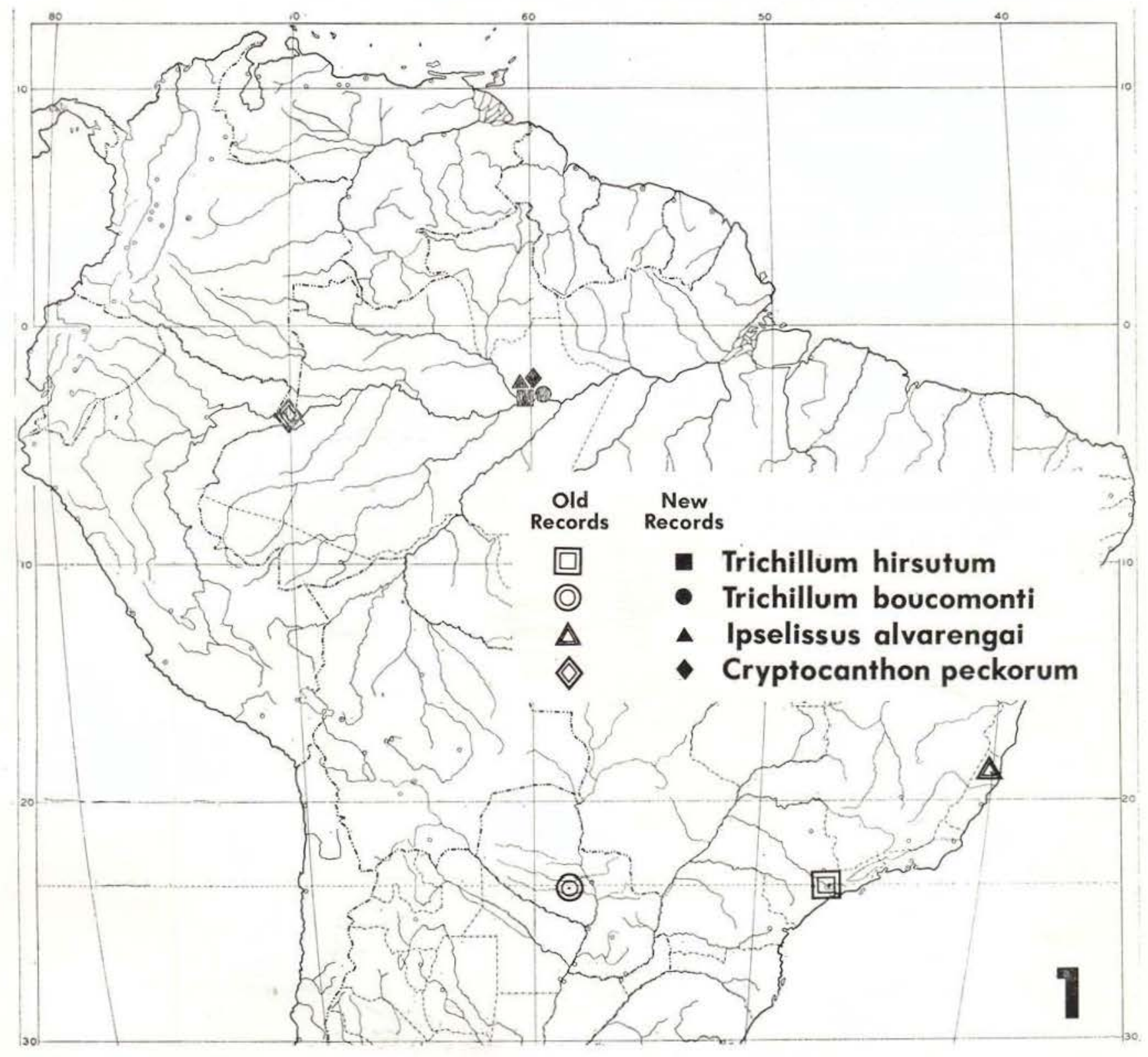

Fig. 1 - Distribution map showing old and new collecting records for the species listed.

lected from baited pitfall traps in primary forest (2 specimens) and secondary forest (37 specimens) during two trapping programs lasting 56 and 43 weeks re. spectively as follows: feces -28 specimens; carrion -11 specimens. A two to one preference for feces is indicated by the trapping results. New State Record. Previously known only from the state of Espirito Santo in SE Brazil (Pereira \& Martinez, 1963) which is approximately 2900 $\mathrm{km}$ distant.

\section{ACKNOWLEDGEMENT}

I would like to express my grateful appreciation to $A$. Descarpentries (Muséum National d'Histoire Naturelle, Paris) for loaning me Boucomont's type of $T$. hirsutum.

\section{Resumo}

Trichillum hirsutum Boucomont (Coleoptera: Scarabaeidae: Scarabaeinae) é redescrito porque a descrição original estava errada. Apresentam-se novos registros de distribuição no Brasil para Trichillum hirsutum Bou- 
comont, Ipselissus alvarengai Pereira and Martinez (novos registros do estado), Trichillum boucomonti Saylor, e Cryptocanthon peckorum Howden (novos registros do pais).

\section{REFERENCES}

ARROW, GILBERT J.

$$
\begin{aligned}
& 1932 \text { - New species of lamellicorn beetles } \\
& \text { (subfam. Coprinae) from South America. } \\
& \text { Stylops } 1: 223-226 .
\end{aligned}
$$

BALthasar, Vladimir

1939 - Monographie der Gattung Trichillum Har. Ceskolovenska Spolecnost Zool., $6: 11-26$.

HOWDEN, H.F.

1973 - Revision of the New World genus Crypto. canthon Balthasar (Coleoptera: Scarabaeidae). Canadian J. Zool., 51(1) : 39-48.

Howden, H.F́. \& Nealis, V.G.

1975 - Effects of clearing in a tropical rain forest on the composition of the coprophagous scarab beetle fauna (Coleoptera). Biotr. $7(2): 77-83$.
MARTINEZ, ANTonio

1967 - Notas para una monografia del genero Trichillum Harold 1868. Rev. Soc. Mexicana Hist. Nat., 28 : 119-147.

Pereira, F.S. \& Martinez, A.

1963 - Notas sobre el genero Ipselissus Olsoufieff (Coleoptera - Scarabaeidae). Acta Zool. Mexicana, $6(6): 1-8$.

RATCliffe, BREtT C.

s.d. - New species of Coprini (Coleoptera: Scarabaeidae: Scarabaeinae) taken from the pelage of three toed sloths (Bradypus tridactylus L.) (Edentata: Bradypodidae) in central Amazonia with a brief commentary on scarab-sloth relationships. Coleop. Bull. (in press).

SAYLOR, LAWRENCE W.

1935 - New species of Trichillum (Col.: Copridae). Stylops, 4(9) : 207-208.

(Aceito para publicação em 17/07/80) 